\title{
MANAGEMENT OF WORK HAZARD IN ORGANIZATION: A STUDY OF NIGERIAN BREWERIES, PLC, ENUGU
}

\author{
ONUORAH, A.N, ONWUKA EBELE AND NWANKWO COSMAS \\ Department of Business Administration \\ Chukwuemeka Odumegwu Ojukwu University \\ lawtonia@yahoo.com \\ 08065130040
}

\begin{abstract}
Many organizations have relegated the safety of their workers to the background. They have compromised with the safety of the workers in the working place. This study examined management of work hazard in organizations. This study specifically examine the relationship between management of work hazard and employee service delivery in Nigerian Breweries, Plc., Enugu which is the objective the researcher want to achieve. The study adopted descriptive design. The population of the study is 474 workers and sample size of 217. Stratification sampling technique was used to select the respondents. . Data obtained from the copies of the questionnaire was analyzed using descriptive statistics, which involved the weighted mean. Pearson's Product-Moment Correlation Coefficient was adopted to establish the relationship between management work hazard programmes and employee performance. The study found out that occupational health surveillance gives the employees the ability to plan and be able to undertake work in an organized manner while identifying priorities. More so, health and safety committees ensure that employees usually put extra effort to complete an assignment on time. The study further recommended that Nigerian Breweries companies should ensure that they use occupational health surveillance so as to give the employees the ability to plan and be able to undertake work in an organized manner while identifying priorities. Nigerian Breweries companies should employ health and safety committees to ensure that employees usually put extra effort to complete an assignment on time.
\end{abstract}

Keywords: Management, Work hazard, Organization

\subsection{INTRODUCTION}

Organizations are set up to achieve specific goals and objectives. Such objectives are achieved by harnessing resources available including human resources. The human resource is the most critical asset of the organization because other assets are inanimate. There is the need to provide the enabling environment for the performance of the job, including motivation of staff and especially their safety for optimum performance. In recent years, some workers have temporarily or permanently been disabled by work related accidents as a result of inadequate safety knowledge on handling machines and equipment, neglecting to follow simple procedure in accomplishing task or management not providing the right safety standards and resources for employees (Collinson, 2010). Many organizations appear to neglect the work hazard within their working environment thereby constituting dangerous threat to the exposure to workers.

However, work hazard is defined as a dangerous phenomenon, substance, human activity, or condition that may cause loss of life, injury, or other health impacts at the workplace (WHO, 
2008). In this study, work hazards are injuries sustained from falls, needle pricks, contact, with infected body fluids from patients, lifting heavy patients and objects, and long periods of standing due to job demands. Work hazard comes in the form of physical hazards and are often associated with an uncontrolled source of energy; kinetic, electrical, pneumatic, hydraulic, to mention these few. Examples of physical hazards are high exposure to sunlight / ultraviolet rays, temperature extremes - hot and cold, and constant loud noise. Biological hazard is another type of workplace hazard. They include blood and other body fluids, fungi/mold, bacteria and viruses, insect bites, and animal and bird droppings to mention these few. There is also safety hazards, which include anything that can cause falls such as working from heights, including ladders, scaffolds, roofs, or any raised work area; unguarded machinery and moving machinery parts that a worker can accidentally touch; and electrical hazards like frayed cords, missing ground pins, improper wiring.

It should be emphasized that accidents, no matter how it happened or occurred in the workplace are costly to both the affected worker's service delivery and theorganisation. Therefore, every effort should be made by management and employees in order to avoid workplace accidents from occurring. However, it becomes important to employ the management of work hazard in the workplace in order to minimize the dangers caused by work hazards. Management of work hazard is a discipline dealing with prevention of work related injuries and diseases, and the protection and promotion of healthy workers. It aims at the improvement of working conditions and environment. Management of work hazard entails the promotion and maintenance of the highest degree of physical and mental health and social well-being of workers in all occupations (Taderera, 2012).

Nevertheless, the major goal of any organization is to increase productivity, but without the safety of the employees and employee service delivery, it becomes mirage. Workplace exposures to work hazard are found in today's work environment and the inability to manage such hazards threatens the health and performance of the employees that would spur the increase in productivity through better service delivery(Health and Safety Executive, 2015). World Health Organization (2013) estimates that over 160 million of new cases of work related illnesses occur every year. International Labour Organization estimates that 2.2 million workers die every year as a result of work related ill-health and injury, 350 thousand of these deaths are due to accidents and the rest due to occupational illness and accidents. In Nigeria, it appears to be the worst since so many organizations do not practice management of work hazard.

According to International Labour Organization (ILO) in Nigeria, many organizations struggle to foster an effective management of workplace hazard by compromising health and safety standards, procedures, policies and programmes thereby exposing the workers to dangers and causing the deaths of many workers (ILO, 2010). Health and safety in the Nigeria work environment appears not to have been given increasing emphasis by managers, employers, employees, trade unions, employers' associations and other stakeholders in recent years and it therefore becomes worrisome. Although, there are some organizations like Nigerian Breweries Plc., Enugu appears to practice the management of work hazard.

Consequently, despite few organizations that practice management work hazard in Nigeria, many of other organizations seem to have no management programmes that would improve the management of work hazard. In addition, the above understanding coupled with the fact that at the core of every business is man whose output is partially dependent on his/her state of health, an appreciation of the concept of workplace health and safety becomes imperative 
to study the management of work hazard in the Nigerian working environment. In order to fill this gap, this study is thus geared towards examining management of work hazard in organization with particular reference to Nigerian Breweries Plc., Enugu that appears to practice it and as well know the work hazard management programmes that have improved the safety of the employees and as well as increase their performance.

\subsection{Statement of the Problem}

Due to none adherence of safety rules and regulations, and ignorance of the imminentdangers associated with manufacturing organizations, work related accidents and incidentsare common, thereby negatively affecting the performance of workers.In today's business organization, the matter of workplace safety and health is receivingworldwide attention. Nevertheless, in a situation where there is lack of attention to safetymanagement, the result has always been high rate of industrial accidents, which hamperseconomic development, since productivity/material output will be low.Thus, the study focuses on the management of work hazard in organizations with particular reference to Nigerian Breweries Plc., Enugu.

\subsection{Objectives of the Study}

The main objective of the study is to examine management of work hazard in organizations with particular reference to Nigerian Breweries Plc., Enugu. The specific objective is to examine the relationship between management of work hazard programmes and employee service delivery in Nigerian Breweries Plc., Enugu.

\subsection{Research Question}

What is the relationship between management of work hazard programmes and employee service delivery in Nigerian Breweries Plc., Enugu?

\subsection{Hypothesis}

This study will test the following hypotheses:

$\mathrm{H}_{1}$ : There is significant relationship between management of work hazard programmes and employee service delivery in Nigerian Breweries Plc., Enugu.

$\mathrm{H}_{0}$ : There is no significant relationship between management of work hazard programmes and employee service delivery in Nigerian Breweries Plc., Enugu.

\subsection{Scope of the Study}

This study is aimed at examining management of work hazard of organizations. However, due to the vast nature of the study, it was limited to Nigerian Breweries Plc., Enugu. Nevertheless, the study is specifically looking at the significant relationship between the management of work hazard programmes of Nigerian Breweries Plc., Enugu and employee service delivery.

\subsection{REVIEW OF RELATED LITERATURE}

\subsection{Conceptual Framework}

\subsubsection{Workplace Hazard}

The International Labour Organization (ILO) defined a work hazard as the inherent potential to cause injury or damage to people's health in the workplace (ILO, 2010). While this conception is open to encompassing all types of hazard, the resultant vagueness makes it difficult to apply. Another commonly used definition that is arguably only slightly more conducive to operational application is the Standards Australia/Standards New Zealand (SA/SNZ). The definition refers to a work hazard as a source or a situation with a potential for harm in terms of human injury or ill-health, damage to property, damage to the 
environment, or a combination of these in the workplace (Standards Australia, 2001). Safe Work Australia adopted a similarly broad approach to work hazard definition in the 2010 draft code of practice developed to support implementation of the national Model Work Health and Safety Act. The definition is given as a situation or thing that has the potential to harm a person in the workplace. Hazards at work may include: noisy machinery, a moving forklift, chemicals, electricity, working at heights, a repetitive job, bullying and violence, a badly designed workplace and inadequate management systems (for example, no procedures for performing tasks safely) (Safework Australia, 2010).

\subsubsection{Management of Work Hazard}

Management of work hazard is a cross-disciplinary area concerned with protecting the safety, health, and welfare of people engaged in work or employment. The goal of all Management of work hazard is to foster a safe work environment (Amazon, 2006). Work health deals with ill-health arising from working conditions/or environment that slowly accumulate to lead to deterioration of the workers health. However occupational safety is concerned with prevention of accidents and minimizing the aspect of work environment that has the potential of causing immediate violent harm to employees (Armstrong, 2012). According Mejia (2010) asserts that Management of work hazard is abroad area, which includes both physical and emotional well-being. Effectively managing workplace safety and health requires far more than reducing the number of job related accidents and injuries. Health and safety is a positive concept that includes social and personal resources as well as physical capabilities (Nutbeam, 1990). It has been conceptualized as the ability to have and to reach goals, meet personal needs and cope with everyday life (Raphael, Brown, Renwick \&Rootman, 1997). The concept of accident proneness is now largely discredited; safety and health programs concentrate as far as possible on ensuring that the employee is suitable for the job and that work is conducted in a safe environment (Graham and Bennet, 1995).

\subsubsection{Management Work Hazard Programmes}

These are programmes that try discovering the causes of accidents and aiming at reducing the accidents. This is a continuous process of enhancing safety and it tries to minimize the effects of accidents (Verman and Mohan, 2010). Sparrow (1998) postulates that the heart of organizations safety programme is accident prevention. Management of work hazard also encompasses all the people and programmes directly or indirectly involved in making the work environment safe. Management of work hazard programs according to Liukkonen et al (1996) play a great role in reduction of cost for the organization the cost through the Workrelated accidents or diseases, which are very costly and can have many serious direct and indirect effects on the lives of workers and their families. It include practical, enterprise level efforts aimed at achieving adequate occupational health and safety such as Medical/health surveillance, Health and Safety Committees, Employee Wellness Programs, Employee Assistance Programs, Health and Safety Policies, Health and Safety Audits, and Health and Safety Training.

\subsubsection{Relationship between Management Work Hazard Programmesand Employee Service Delivery}

The employee job performance can be negatively affected by Occupational health and safety which means if there is lack of high performance in job the organizations performance also gets affected hence also affecting the overall organization performance. For Example: If the workplace is not health hazard proof it will cause a disease among workforce hence negatively affect the employee job performance and organization performance as affirmed byNyakang'o(2009). A concern in principle for the health and safety of employees and 
encouragement of employees self-interest and safety are obvious prerequisites. Workplace reality can be different because of perceptions that health and safety constraints operational freedom and inhibits productivity. Higher performance HR strategies recognize creating an environment where people feel physically and psychologically safe seems to a fairly fundamental demonstration that workers are valued (Pilbeam\&Corbridge, 2010).

\subsection{Theoretical Framework}

\subsubsection{Goal-Freedom Alertness Theory}

Kerr (1950) developed the Goal-Freedom Alertness Theory and it states that safe work performance is the result of psychologically rewarding work environment. Under this theory, accidents are viewed as low-quality work behaviour occurring in an unrewarding psychological climate. This contributes to a lower level of alertness. According to the theory, a rewarding psychological climate is one where workers are encouraged to participate, set sustainable goals and choose methods or safety programmes to attain those safety and health goals. They must be allowed to participate in raising and solving problems.

Goal-Freedom Alertness Theory essentially states that management should let workers have well defined goals and freedom to pursue those goals. The result is a higher level of alertness and a focus on the tasks at hand. The theory suggests that managers and supervisors should try and make work more rewarding for workers. They may use a variety of managerial techniques including positive reinforcements, goal setting participative management and clear work assignments. Heinrich et.al (1980) supports the theory by stating workers will be safe in a positive work environment. They argue that safe performance is compromised by a climate that diverts the attention of workers. They confirm that hazards divert the workers attention during work hours and thus the diversion increases susceptibility to injury. Heinrich et. al (1980) suggests that managers and supervisors can actively work to alleviate hazards in the work environment. Reaction of workers to unsafe conditions depends on the fact that whether the worker identifies the unsafe condition

\begin{tabular}{|l|l|l|l|}
\hline Author (Year) & Topics/Place & Methodology & Findings \\
\hline Jelimo (2013) & $\begin{array}{l}\text { The effects of } \\
\text { occupational } \\
\text { health and safety } \\
\text { practices on } \\
\text { employee } \\
\text { productivity. }\end{array}$ & $\begin{array}{l}\text { Cross-sectional are } \\
\text { design.SurveyDesign.A } \\
\text { sample size of 200.Chi- } \\
\text { square }\end{array}$ & $\begin{array}{l}\text { Thereralth } \\
\text { occupational health } \\
\text { and safety practices } \\
\text { that have positive } \\
\text { relationship with } \\
\text { productivity of } \\
\text { employees and } \\
\text { include; fire } \\
\text { prevention and } \\
\text { protection etc. }\end{array}$ \\
\hline Mberia (2010) & $\begin{array}{l}\text { Occupational } \\
\text { health and safety } \\
\text { programmes } \\
\text { adopted by banks } \\
\text { operating } \\
\text { Kenya. in }\end{array}$ & $\begin{array}{l}\text { Regression ample size of 150 } \\
\text { participants }\end{array}$ & $\begin{array}{l}\text { Banks are very keen } \\
\text { on physical and } \\
\text { mechanical hazards } \\
\text { that affect } \\
\text { employees thereby } \\
\text { increasing workers' } \\
\text { productivity }\end{array}$ \\
\hline Makori (2008) & $\begin{array}{l}\text { Safety } \\
\text { management } \\
\text { programmes and }\end{array}$ & $\begin{array}{l}\text { A primary and secondary } \\
\text { source of data.Descriptive } \\
\text { statistics and Chi-square }\end{array}$ & $\begin{array}{l}\text { Reduction of } \\
\text { hazards increases } \\
\text { employee }\end{array}$ \\
\hline
\end{tabular}




\begin{tabular}{|c|c|c|c|}
\hline & $\begin{array}{l}\text { employee } \\
\text { productivity in } \\
\text { Gambia }\end{array}$ & $\begin{array}{l}\text { inferential statistics. } 535 \\
\text { participants }\end{array}$ & productivity \\
\hline $\begin{array}{l}\text { Gyekye\&Salminen, } \\
(2015)\end{array}$ & $\begin{array}{l}\text { Hazard } \\
\text { management } \\
\text { practices in five } \\
\text { dimensions, i.e. } \\
\text { safety procedures } \\
\text { and risk } \\
\text { management, } \\
\text { safety and health } \\
\text { rules, first aid } \\
\text { support and } \\
\text { training, } \\
\text { occupational } \\
\text { accident } \\
\text { prevention, and } \\
\text { organizational } \\
\text { safety support. In } \\
\text { Turkey }\end{array}$ & $\begin{array}{l}\text { Qualitative and survey } \\
\text { method. A sample size of } \\
443 \text { participants }\end{array}$ & $\begin{array}{l}\text { Employees consider } \\
\text { organization's } \\
\text { commitment for } \\
\text { safety as a kind of } \\
\text { perceived } \\
\text { organizational } \\
\text { support and in the } \\
\text { long run, increase } \\
\text { productivity }\end{array}$ \\
\hline $\begin{array}{l}\text { Barling and } \\
\text { Hutchinson (2010) }\end{array}$ & $\begin{array}{l}\text { Safety practices } \\
\text { and employee's } \\
\text { commitment to } \\
\text { work in London }\end{array}$ & \begin{tabular}{ll} 
Regression & \multicolumn{2}{c}{ analysis. } \\
Sample size of 150 \\
participants
\end{tabular} & $\begin{array}{l}\text { Commitment-based } \\
\text { safety practices } \\
\text { improved trust and } \\
\text { organizational } \\
\text { commitment and } \\
\text { indirectly and } \\
\text { directly influenced } \\
\text { the safety climate } \\
\text { and employee } \\
\text { productivity }\end{array}$ \\
\hline
\end{tabular}

2.3 Empirical Analysis/Webometric

\begin{tabular}{|l|l|l|l|}
\hline $\begin{array}{l}\text { Author } \\
\text { Year) }\end{array}$ & Topics/Place & Methodology & Findings \\
\hline $\begin{array}{l}\text { Umoh and } \\
\text { Torbira }\end{array}$ & $\begin{array}{l}\text { The nature of the } \\
\text { relationship between } \\
\text { safety practices and the } \\
\text { productivity of } \\
\text { employees } \\
\text { manufacturing firms in } \\
\text { Port Harcourt in }\end{array}$ & $\begin{array}{l}\text { 2,000 } \\
\text { Survey design method } \\
\text { Contingency chi-square } \\
\left(X^{2}\right)\end{array}$ & $\begin{array}{l}\text { There is a significant } \\
\text { relationship between } \\
\text { employer's } \\
\text { compliance to safety } \\
\text { rule and man-hour put } \\
\text { in by employees in the } \\
\text { production process. }\end{array}$ \\
\hline $\begin{array}{l}\text { Nwachukwu, } \\
(2012)\end{array}$ & $\begin{array}{l}\text { Effect of industrial } \\
\text { safety management on } \\
\text { employee performance } \\
\text { in Owerri, Imo State. }\end{array}$ & $\begin{array}{l}\text { Population of 1220 and } \\
\text { sample size of 301. } \\
\text { Descriptive statistics, Z- } \\
\text { test and Friedman Chi- } \\
\text { square }\end{array}$ & $\begin{array}{l}\text { There were significant } \\
\text { relationship between } \\
\text { industrial safety } \\
\text { management and } \\
\text { employee } \\
\text { performance }\end{array}$ \\
\hline $\begin{array}{l}\text { Ngwama } \\
(2016)\end{array}$ & $\begin{array}{l}\text { Occupational Health and } \\
\text { Safety programmes and }\end{array}$ & $\begin{array}{l}\text { A primary and } \\
\text { secondary source of }\end{array}$ & $\begin{array}{l}\text { Reduction of hazards } \\
\text { increases employee }\end{array}$ \\
\hline
\end{tabular}




\begin{tabular}{|c|c|c|c|}
\hline & $\begin{array}{l}\text { employee productivity in } \\
\text { Enugu State }\end{array}$ & $\begin{array}{l}\text { data.Descriptive } \\
\text { statistics and Chi-square } \\
\text { inferential statistics. } \\
1,535 \text { respondents }\end{array}$ & productivity \\
\hline Lowe (2014) & $\begin{array}{l}\text { Safety practices and } \\
\text { employee performance } \\
\text { in Aba, Abia State }\end{array}$ & $\begin{array}{l}\text { Descriptive design. A } \\
\text { sample size of } 200 . \\
\text { Frequency tables and } \\
\text { percentages }\end{array}$ & $\begin{array}{l}\text { Safety practices give } \\
\text { employees confidence } \\
\text { in achieving its } \\
\text { strategic goals. }\end{array}$ \\
\hline $\begin{array}{l}\text { Onuegbu } \\
(2010)\end{array}$ & $\begin{array}{l}\text { A safe and healthy } \\
\text { workplace in Edo State. }\end{array}$ & $\begin{array}{ll}\text { Regression } & \text { analysis. } \\
\text { Sample size of } 150 \\
\text { participants }\end{array}$ & $\begin{array}{lr}\text { Prominent } & \text { safety } \\
\text { measures } & \text { increase } \\
\text { productivity } & \end{array}$ \\
\hline $\begin{array}{l}\text { Chen and } \\
\text { Chan (2014) }\end{array}$ & $\begin{array}{l}\text { Safety management and } \\
\text { workers' productivity }\end{array}$ & $\begin{array}{l}\text { Survey Design.Simple } \\
\text { size of } 450 . \text { Regression } \\
\text { analysis }\end{array}$ & $\begin{array}{l}\text { Safety management } \\
\text { increases employee's } \\
\text { effectiveness and } \\
\text { quality services }\end{array}$ \\
\hline Sikpa (2011) & $\begin{array}{l}\text { An assessment of } \\
\text { occupational health and } \\
\text { safety practices on job } \\
\text { performance at the } \\
\text { TettehQuarshire } \\
\text { Memorial Hospital in } \\
\text { Ghana }\end{array}$ & $\begin{array}{lr}200 \text { respondents. Survey } \\
\text { design } & \text { method } \\
\text { Contingency } & \text { chi-square } \\
\left(\mathrm{X}^{2}\right) & \end{array}$ & $\begin{array}{l}\text { Effective occupational } \\
\text { safety and health } \\
\text { practices of both } \\
\text { employer and } \\
\text { employees increase } \\
\text { job performance }\end{array}$ \\
\hline $\begin{array}{l}\text { Badakale } \\
(2012)\end{array}$ & $\begin{array}{l}\text { Effects of work hazard } \\
\text { and safety policies on } \\
\text { employee performance } \\
\text { in Larfage (WAPCO) } \\
\text { PLC, Ewekoro, Ogun } \\
\text { State in Nigeria }\end{array}$ & $\begin{array}{l}\text { Descriptive } \\
\text { statistics.Chi-square. A } \\
\text { sample size of } 300\end{array}$ & $\begin{array}{l}\text { Providing a safe } \\
\text { working environment } \\
\text { and a good safety } \\
\text { policy improves } \\
\text { employee } \\
\text { performance }\end{array}$ \\
\hline $\begin{array}{l}\text { Musyoka } \\
\text { (2014) }\end{array}$ & $\begin{array}{l}\text { The relationship } \\
\text { between work hazard } \\
\text { management } \\
\text { programmes } \\
\text { performance and } \\
\text { manufacturing firms in } \\
\text { Mombasa } \\
\text { Kenya. County, }\end{array}$ & $\begin{array}{l}\text { Descriptive statistics and } \\
\text { regression analysis. } 250 \\
\text { participants }\end{array}$ & $\begin{array}{lr}\text { There is positive } \\
\text { effect on work } \\
\text { performance } \\
\text { safety programmes are } \\
\text { practiced }\end{array}$ \\
\hline
\end{tabular}

\subsection{Gap in Literature}

Many empirical studies were reviewed. Some were carried in Nigeria such as Onuegbu (2010) and Badakale (2012) while others were carried out in outside Nigeria such as Musyoka (2014) and Barling and Hutchinson (2000). However, their findings, based on the years and location might not be the same in the present economic reality with Nigeria especially Nigerian Breweries Plc., Enugu. In order to fill this, this study therefore seeks to examine management of work hazard in organizations with particular study of Nigerian Breweries Plc.,

\subsection{METHODOLOGY}

\subsection{Research Design}

The study adopted Descriptive research design in form of a survey. The design is found appropriate because according to Cooper and Schindler (2003), descriptive design are used to 
describe phenomena associated with a subject population or to estimate proportions of the population that have certain characteristics.

\subsection{Population of the Study}

In this study, the target population comprised employees of Nigerian Breweries Plc., Enugu. Nigerian Breweries Plc., Enugu has a total population of 474 employees according to the Human Resource Department. Hence, the total population of the study was 474 (Nigerian Breweries Plc., Enugu - Human Resource Department, 2018)(See appendices for details).

\subsection{Sample Size and Sampling Technique}

The method of selection of the respondents was done through stratified random sampling, which classifies the population into strata and ensures all the departments, units and sections are represented. Stratified random sampling is a process by which the sample is constrained to include elements from each of the segments and it is useful when the researcher.The sample size was obtained through Taro Yamane's formula, which is given as;

$\mathrm{n}=\frac{\mathrm{N}}{1+\mathrm{N}(\mathrm{e})^{2}}$

Where:

$\mathrm{n}=$ Sample size

$\mathrm{N}=$ Total Population

$\mathrm{e}=$ sampling error $(0.05)$ or $5 \%$

Where $\mathrm{N}=474$

$$
\begin{aligned}
& \mathrm{n}=\frac{474}{1+474(0.05)^{2}} \\
& \mathrm{n}=\frac{474}{1+443(0.0025)} \\
& \mathrm{n}=\frac{474}{1+1.185} \\
& \mathrm{n}=\frac{474}{2.185}=216.93
\end{aligned}
$$

Hence, approximately, the sample size of the study is 217 .

\subsection{Data Collection}

The study used quantitative data collection methods. Primary data was collected mainly by use of structured questionnaires. A Five Point Likert Scale such as Strongly Agree (SA) =5, Agree $(A)=4$, Disagree $(D)=3$, Strongly Disagree $(S D)=2$, and Undecided $(U D)=1$ was used to determine the degree to the relationship between management work hazard programmes and performance of employees at Nigerian Breweries Plc., Enugu. The questionnaire was divided into two sections; the first section isfor the instrument of management of work hazard; and the second section is for employee performance;all contained questions that are in line with specific objective of the study. The respondents were required to fill the questionnaires at their own convenient time to avoid inconvenience during work hours. Drop and pick method and e-mail correspondence was used to administer the questionnaires and the response was picked after fourteen (14) days.

\subsection{Validity of the Instrument}

The questionnaire developed for this study was subjected to content validity. Content validity is the extent which measuring instrument provides adequate coverage of the topic under study 
(Onyeizugbe, 2013). The questionnaire was designed in a very simple language to avoid ambiguity, misinterpretation, or misunderstanding of the questions or statements. The questions in the questionnaire were well structured in line with the objective of the study. The instrument was subjected to experts' evaluation in measurement and management from which necessary corrections were made before the questionnaire was distributed to respondents.

\subsection{Reliability of the Instrument}

The instrument was pilot tested using Cronbach Alpha method. Twenty (20) workers in Life Breweries Co. Ltd, Onitsha, Anambra State were used to determine the reliability of the instrument. The computed score for the instrument of management of work hazard $=0.748$; and employee performance $=0.714$ (see appendix $\mathrm{M}$ for more details). The analysis yielded an average reliability coefficient value of 0.731 . This value was high and therefore considered reliable for the study (See appendices for details).

\subsection{Method of Data Analysis}

Data was checked for accuracy, uniformity, logical completeness, and consistency before analysis. Data obtained from the copies of the questionnaire was analyzed using descriptive statistics, which involved the weighted mean. Pearson's Product-Moment Correlation Coefficient was adopted to establish the relationship between management work hazard programmes and employee performance in Nigerian Breweries Plc., Enugu with the help of SPSS ver.22. The hypothesis was tested at 5\% level of significance and the confidence interval of $95 \%$.

\subsection{DATA PRESENTATION AND ANALYSIS}

A total number of 217 copies of the questionnaire were administered to the respondents using three research assistants. 200 copies of the questionnaire that were fully and properly filled were retrieved giving a recovery rate of $92.17 \%$.

\subsection{Questionnaire Analysis}

Table 1: Questionnaire Analysis

\begin{tabular}{|c|c|c|c|c|c|c|c|c|c|}
\hline $\mathbf{S} / \mathbf{N}$ & Item Descriptions & \multicolumn{8}{|c|}{ Responses } \\
\hline & & $\mathbf{S A}$ & $\mathbf{A}$ & D & SD & $\mathbf{U}$ & $\mathbf{T}$ & $\overline{\bar{X}}$ & Decision \\
\hline & $\begin{array}{c}\text { Management Work } \\
\text { Hazard Programmes }\end{array}$ & 5 & 4 & 3 & 2 & 1 & & & \\
\hline 1 & $\begin{array}{l}\text { Occupational Health } \\
\text { Surveillance }\end{array}$ & $\begin{array}{c}58 \\
(290)\end{array}$ & $\begin{array}{c}57 \\
(228)\end{array}$ & $\begin{array}{c}35 \\
(105)\end{array}$ & $\begin{array}{r}30 \\
(60) \\
\end{array}$ & $\begin{array}{r}20 \\
(21)\end{array}$ & $\begin{array}{c}200 \\
(703)\end{array}$ & 3.52 & Agree \\
\hline 2 & $\begin{array}{l}\text { Health and safety } \\
\text { committees }\end{array}$ & $\begin{array}{c}74 \\
(370) \\
\end{array}$ & $\begin{array}{c}59 \\
(236) \\
\end{array}$ & $\begin{array}{c}24 \\
(72)\end{array}$ & $\begin{array}{r}23 \\
(46) \\
\end{array}$ & $\begin{array}{l}20 \\
(20) \\
\end{array}$ & $\begin{array}{c}200 \\
(744)\end{array}$ & 3.72 & Agree \\
\hline 3 & $\begin{array}{l}\text { Employee assistance } \\
\text { program }\end{array}$ & $\begin{array}{c}46 \\
(230)\end{array}$ & $\begin{array}{r}69 \\
(276) \\
\end{array}$ & $\begin{array}{r}39 \\
(117) \\
\end{array}$ & $\begin{array}{r}25 \\
(50) \\
\end{array}$ & $\begin{array}{r}21 \\
(21) \\
\end{array}$ & $\begin{array}{r}200 \\
(694)\end{array}$ & 3.47 & Agree \\
\hline 4 & $\begin{array}{l}\text { Health and Safety } \\
\text { Audits }\end{array}$ & $\begin{array}{c}55 \\
(275)\end{array}$ & $\begin{array}{c}68 \\
(272)\end{array}$ & $\begin{array}{c}33 \\
(99)\end{array}$ & $\begin{array}{r}24 \\
(48) \\
\end{array}$ & $\begin{array}{r}20 \\
(20)\end{array}$ & $\begin{array}{c}200 \\
(714)\end{array}$ & 3.57 & Agree \\
\hline 5 & $\begin{array}{l}\text { Health and safety } \\
\text { Policy }\end{array}$ & $\begin{array}{c}40 \\
(200)\end{array}$ & $\begin{array}{c}64 \\
(256) \\
\end{array}$ & $\begin{array}{c}34 \\
(102)\end{array}$ & $\begin{array}{r}33 \\
(66) \\
\end{array}$ & $\begin{array}{r}29 \\
(29) \\
\end{array}$ & $\begin{array}{r}200 \\
(653)\end{array}$ & 3.27 & Agree \\
\hline
\end{tabular}




\begin{tabular}{|c|c|c|c|c|c|c|c|c|c|}
\hline & $\begin{array}{c}\text { Employee Service } \\
\text { Delivery }\end{array}$ & & & & & & & & \\
\hline 6 & $\begin{array}{l}\text { I have the ability to } \\
\text { plan and be able to } \\
\text { undertake work in an } \\
\text { organized } \\
\text { manner while } \\
\text { identifying priorities }\end{array}$ & $(200)$ & (200) & (168) & (66) & (21) & $(655)$ & 3.28 & Agree \\
\hline 7 & $\begin{array}{l}\text { I usually put extra effort } \\
\text { to complete an } \\
\text { assignment on time. }\end{array}$ & $\begin{array}{c}40 \\
(200)\end{array}$ & $\begin{array}{c}50 \\
(200) \\
\end{array}$ & $\begin{array}{c}50 \\
(150) \\
\end{array}$ & $\begin{array}{r}40 \\
(80) \\
\end{array}$ & $\begin{array}{l}20 \\
(20)\end{array}$ & $\begin{array}{r}200 \\
(650)\end{array}$ & 3.25 & Agree \\
\hline 8 & $\begin{array}{l}\text { I am allowed to } \\
\text { participate in evaluating } \\
\text { my performance (self - } \\
\text { evaluation) }\end{array}$ & $\begin{array}{c}46 \\
(230)\end{array}$ & $\begin{array}{c}69 \\
(276)\end{array}$ & $\begin{array}{c}39 \\
(117)\end{array}$ & $\begin{array}{r}25 \\
(50)\end{array}$ & $\begin{array}{l}21 \\
(21)\end{array}$ & $\begin{array}{r}202 \\
(694)\end{array}$ & 3.47 & Agree \\
\hline 9 & $\begin{array}{l}\text { I have the ability to } \\
\text { manage people, inspires } \\
\text { others, delegate duties, } \\
\text { direct, } \\
\text { co-ordinate and develop }\end{array}$ & $(255)$ & $(252)$ & (108) & (48) & (26) & (689) & 3.52 & Agree \\
\hline 10 & $\begin{array}{l}\text { I use my skills and } \\
\text { knowledge to } \\
\text { accomplish my tasks }\end{array}$ & $\begin{array}{c}58 \\
(290)\end{array}$ & $\begin{array}{c}57 \\
(228)\end{array}$ & $\begin{array}{c}35 \\
(105)\end{array}$ & $\begin{array}{c}30 \\
(90)\end{array}$ & $\begin{array}{l}20 \\
(20)\end{array}$ & $\begin{array}{l}200 \\
(703)\end{array}$ & 3.52 & Agree \\
\hline
\end{tabular}

\section{Source:Field Survey, 2018.}

The results in table 1 revealed that items 1 to 5 have mean scores of 3.52, 3.72, 3.47, 3.57, and 3.27 respectively in management work hazard programmes. Thus, they were all agreed. Likewise, items 6 to 10 have mean scores of $3.28,3.25,3.47,3.45,3.52$, and 3.52 respectively. Thus, indicating that all items were accepted.

\subsection{Test of Hypothesis}

$\mathrm{H}_{1}$ : There is significant relationship between management of work hazard programmes and employee service delivery in Nigerian Breweries Plc., Enugu.

$\mathrm{H}_{0}$ : There is no significant relationship between management of work hazard programmes and employee service deliveryin Nigerian Breweries Plc., Enugu.

\section{Correlations}

\begin{tabular}{|ll|r|r|}
\hline & & $\begin{array}{c}\text { Management of } \\
\text { work hazard } \\
\text { programmes }\end{array}$ & $\begin{array}{c}\text { Employee } \\
\text { service delivery }\end{array}$ \\
\hline Management of work hazard & Pearson Correlation & 1 & $.992^{* * *}$ \\
programmes & Sig. (2-tailed) & 200 & .000 \\
& $\mathrm{~N}$ & $.992^{* *}$ & 200 \\
Employee service delivery & Pearson Correlation & .000 & 1 \\
& Sig. (2-tailed) & 200 & 200 \\
\hline
\end{tabular}

**. Correlation is significant at the 0.01 level (2-tailed). 
The results of the test of hypothesis two revealed that $p(.001)<.05$. Therefore, the null hypothesis is rejected. Thus, there is significant relationship between management of work hazard programmes and employee service delivery in Nigerian Breweries Plc., Enugu. More so, the r-value is .992 indicating that there is a strong positive relationship between management of work hazard programmes and employee service delivery. This implies that when organizations apply safety measures with strictness, the workers remain safe while working thereby increasing their effective service delivery and productivity.

\subsection{Discussions of the Findings}

Occupational health surveillance gives the employees the ability to plan and be able to undertake work in an organized manner while identifying priorities. More so, health and safety committees ensure that employees usually put extra effort to complete an assignment on time. In addition, employee assistance program stimulates employees to have the ability to manage people, inspires others, delegate duties, direct, co-ordinate and develop; health and safety policy ensures that employees use their skills and knowledge to accomplish my tasks; and health and safety audits ensures that employees are kept in check so as to keep them free from work hazard. These findings are in line with Umoh and Torbira (2013), Ngwama (2016), Lowe (2014), and Barling and Hutchinson (2000) findings that safety practices give employees confidence in achieving its strategic goals. In addition, commitment-based safety practices improved trust and organizational commitment and indirectly and directly influenced the safety climate and employee productivity.

\subsection{SUMMARY, CONCLUSIONS AND RECOMMENDATIONS}

\subsection{Summary of Findings}

Based on the findings of the study, it would be stated that:

1. Occupational health surveillance gives the employees the ability to plan and be able to undertake work in an organized manner while identifying priorities.

2. Health and safety committees ensures that employees usually put extra effort to complete an assignment on time.

3. Employee assistance program stimulates employees to have the ability to manage people, inspires others, delegate duties, direct, co-ordinate and develop

4. Health and safety policy ensures that employees use their skills and knowledge to accomplish my tasks, and

5. Health and safety audits ensures that employees are kept in check so as to keep them free from work hazard.

\subsection{Conclusion}

Management of work hazard programmeshas greater influence on employee service delivery.This is because when organizations apply safety measures with strictness, the workers remain safe while working thereby increasing their effective service delivery and productivity.The employees give in their best whenever there are safety proactive measures to ensure that they are safe from harms and work hazard.

\subsection{Recommendations}

The following recommendations are made based on the findings of the study.

1. Nigerian Breweries companies should ensure that they use occupational health surveillanceso as to give the employees the ability to plan and be able to undertake work in an organized manner while identifying priorities.

2. Nigerian Breweries companiesshould employ health and safety committees to ensure that employees usually put extra effort to complete an assignment on time. 
3. Nigerian Breweries companiesshould use employee assistance programso as tostimulates employees to have the ability to manage people, inspires others, delegate duties, direct, co-ordinate and develop.

4. Nigerian Breweries companiesshould use health and safety policyso as to ensure that employees use their skills and knowledge to accomplish my tasks, and

5. Health and safety audits ensures that employees are kept in check so as to keep them free from work hazard.

\section{References}

Badelake O. F (2012).The Effects of occupational health and safety practices on employee performance in Larfage (WAPCO) PLC - Ewekoro, Ogun State, Unpublished University of Ibadan Nigeria

Barling J.\& Hutchinson, K. (2010).Development and test of a model linkingsafety-specific transformational leadership and occupational safety.Journal of Applied Psychology, $87,488-496$,

Chena, M.\& Chan, A. (2004).Employee and union inputs into occupational health and safety measures in Chinesefactories.Social Science \& Medicine, 58 (2004) 1231-1245

Collinson, D.L. (2010).Surviving the Rigs: Safety and Surveillance in North Sea Oil Installations.Organization Studies, 20: 579-600.

Health and Safety Executive (2001).A guide to measuring health and safety performance.HSE, Retrieved from:http://www.hse.gov.uk/opsunit/perfmeas.pdf.

Gyekye, S.A.\&Salminen, A. (2010). Occupational safety management: The role of causal attribution.International Journal of Psychology, 45(6), 405-416.

Iwundu, A.E.(2016). Concept of Accident Prevention.A seminar paper: Federal Ministry of Employment, Labour and Productivity, Owerri.

International Labour Organization (2010).Decent Work Country Programme 2014-15: Ethiopia/International Labour Organization, ILO Country Office for Ethiopia and Somalia. - Addis Ababa: ILO, 2014

Jelimo M. S. (2013).The Effects of Occupational Health and Safety on Employee Productivity (Descriptive Study), Unpublished, Moi University, Kenya.

Kerr, W. A. (1950).Accident proneness of factory departments.Journal of Applied Psychology, XXXIV(June, 1950), 167-170.

Lowe, G. S. (2014) Healthy workplace strategies: creating change and achieving results,http://www.hcsc. gc.ca/ewh-semt/occup-travail/work-travail/whr-rmteng.

Makori, E. M. (2008) Influence of occupational health and safety programmers on performance of manufacturing firms in Western Province, Kenya. African Journal of History and Culture (AJHC), 4(4), 46-58. 
Mberia, A. M. (2010). A survey of the occupational health \& safety programmes adopted by the banking industry in Kenya; An Empirical Study; MBA Project;University Of Nairobi.

Ngwama, J. C. (2016). Occupational Health and Safety programmes and employee productivity in Enugu State. Journal of Economics and Sustainable Development, Vol.7, No.11,

Nwachukwu, C.C. (2012), Management theory and practice.Lagos, Africana PEPPublishers.

Nyakang'o J. B. (2009). Status of occupational health and safety in Kenya.Workshop on the IUPAC-UNESCO-UNIDO Safety TrainingProgram, part of the IUPAC Congress in Bejing, onWednesday, August 17,2005.

Onuegbu,C. H. (2010). A safe and healthy workplace in Edo State. Emerging Risks and New Patterns of Prevention in a Changing World of Work Being aPaper Presented at 2010 World day for Safety and Health at Work 28 April 2010 Organised by the Federal MinistryofLabour\& Productivity

Sikpa F.C. (2011).An assessment of occupational health and safety practices on job performance at the TettehQuashire Memorial Hospital, ManopangAkuapan, Kwame Nkrumah University Publishers, Ghana.

Taderera, H. (2012).Occupational Health and Safety Management Systems: Institutional and Regulatory Frameworks in Zimbabwe.International Journal of Human Resource Studies, 4, 99-117.

Umoh, G.I.\&Torbira, L. T. (2013). Safety practices and the productivity of employees in manufacturing firms: Evidence from Nigeria.International Journal of Business and Management Review, 1(3), 128-137.

World Health Organization.Global (2008).Strategy objectives and actions for occupational health for all. 1994. [cited 2008 Sep 2]. Available from: URL: http://www.who.int/occupational_health/publications/globstrategy/en/index6.html.

World Health Organization (2007).Resolution 60.26.Workers' health: global plan of action.In: Sixtieth World Health Assembly, Geneva 13-23 May 2007. Geneva.

WHO (2013).Healthy workplace framework and model: Background and supporting literature and practices, WHO Press, Geneva, Switzerlan 


\section{QUESTIONNAIRE:}

\section{APPENDIXES}

Please tick $(\sqrt{ })$ in the appropriate boxes provided

Personal Data

Gender: Male ( ) Female ( )

$\mathrm{SA}=$ Strongly Agree $; \mathrm{A}=$ Agree $; \mathrm{D}=$ Disagree $; \mathrm{SD}=$ Strongly Disagree $; \mathrm{UD}=$ Undecided

\begin{tabular}{|c|c|c|c|c|c|c|}
\hline \multirow[t]{2}{*}{$\mathbf{S} / \mathbf{N}$} & ITEM DESCRIPTIONS & SA & A & D & SD & $\mathbf{N}$ \\
\hline & MANAGEMENT WORK HAZARD PROGRAMMES & 5 & 4 & 3 & 2 & 1 \\
\hline 1 & Occupational Health Surveillance & & & & & \\
\hline 2 & Health and safety committees & & & & & \\
\hline 3 & Employee assistance program & & & & & \\
\hline 4 & Health and Safety Audits & & & & & \\
\hline 5 & Health and safety policy & & & & & \\
\hline \multicolumn{7}{|c|}{ EMPLOYEE SERVICE DELIVERY } \\
\hline 6 & $\begin{array}{l}\text { I have the ability to plan and be able to undertake work in an } \\
\text { organized manner while identifying priorities }\end{array}$ & & & & & \\
\hline 7 & I usually put extra effort to complete an assignment on time. & & & & & \\
\hline 8 & $\begin{array}{l}\text { I am allowed to participate in evaluating myperformance (self - } \\
\text { evaluation) }\end{array}$ & & & & & \\
\hline 9 & $\begin{array}{l}\text { I have the ability to manage people, inspires others, delegate } \\
\text { duties, direct, co-ordinate and develop }\end{array}$ & & & & & \\
\hline 10 & I use my skills and knowledge to accomplish my tasks & & & & & \\
\hline
\end{tabular}

Reliability Results of the Instrument of Employee Service Delivery

\section{Case Processing Summary}

\begin{tabular}{|ll|r|r|}
\hline & & $\mathrm{N}$ & \multicolumn{2}{|c|}{$\%$} \\
\hline \multirow{3}{*}{ Cases } & Valid & 20 & 100.0 \\
& Excluded $^{\mathrm{a}}$ & 0 & .0 \\
& Total $^{*}$ & 20 & 100.0 \\
\hline
\end{tabular}

a. Listwise deletion based on all variables

in the procedure.

Reliability Statistics

\begin{tabular}{|r|r|r|}
\hline $\begin{array}{c}\text { Cronbach's } \\
\text { Alpha }\end{array}$ & $\begin{array}{c}\text { Cronbach's } \\
\text { Alpha Based } \\
\text { on } \\
\text { Standardized } \\
\text { Items }\end{array}$ & N of Items \\
\hline .748 & .748 & 5 \\
\hline
\end{tabular}

Reliability Results of the Instrument of Management of Work Hazard Programes Case Processing Summary

\begin{tabular}{|ll|r|r|}
\hline & & $\mathrm{N}$ & \multicolumn{2}{|c|}{$\%$} \\
\hline \multirow{3}{*}{ Cases } & Valid $^{*}$ & 20 & 100.0 \\
& Excluded $^{\mathrm{a}}$ & 0 & .0 \\
& Total & 20 & 100.0 \\
\hline
\end{tabular}

a. Listwise deletion based on all variables in the procedure. 


\section{Reliability Statistics}

\begin{tabular}{|r|r|r|}
\hline \multicolumn{2}{|c|}{ Cronbach's Alpha } & $\begin{array}{c}\text { Cronbach's Alpha Based on } \\
\text { Standardized Items }\end{array}$ \\
\hline .714 & .714 & N of Items \\
\hline
\end{tabular}

Results of the Relationship between Management of Work Hazard Programes and Employee service delivery

Descriptive Statistics

\begin{tabular}{|l|r|r|r|}
\hline & \multicolumn{1}{|c|}{ Mean } & \multicolumn{1}{|c|}{ Std. Deviation } & N \\
\hline Management of work hazard & 17.54 & 6.424 & 200 \\
programmes & 16.96 & 6.327 & 200 \\
Employee service delivery & & & \\
\hline
\end{tabular}

\section{Correlations}

\begin{tabular}{|ll|r|r|}
\hline & & $\begin{array}{c}\text { Management of } \\
\text { work hazard } \\
\text { programmes }\end{array}$ & $\begin{array}{r}\text { Employee service } \\
\text { delivery }\end{array}$ \\
\hline Management of work hazard & Pearson Correlation & 1 & $.992^{* * *}$ \\
programmes & Sig. (2-tailed) & 200 & .000 \\
& $\mathrm{~N}$ & $.992^{* *}$ & 200 \\
Employee service delivery & Pearson Correlation & .000 & 1 \\
& Sig. (2-tailed) & 200 & 200 \\
\hline
\end{tabular}

**. Correlation is significant at the 0.01 level (2-tailed).

Summary of the Departments in Nigerian Breweries Plc., Enugu

\begin{tabular}{|l|c|c|}
\hline Category & No. of Employees & Percentage \\
\hline Support and Development Department & 89 & 19 \\
\hline Finance Department & 32 & 7 \\
\hline Logistic Department & 53 & 11 \\
\hline Quality Assurance Unit & 41 & 9 \\
\hline Production Department/Brew House & 115 & 24 \\
\hline Packaging and Engineering Department & 144 & 30 \\
\hline Total & $\mathbf{4 7 4}$ & $\mathbf{1 0 0}$ \\
\hline
\end{tabular}

Source: Nigerian Breweries Plc., Enugu, 2018. 